\title{
Was there a Scientific Revolution?
}

\author{
PETER HARRIS ON \\ Harris Manchester College, Mansfield Road, Oxford OX1 3TD, UK. \\ Email: peter.harrison@hmc.ox.ac.uk
}

\begin{abstract}
During the middle decades of the twentieth century, the Scientific Revolution came to be understood as a key period in Western history. Recently, historians have cast doubt upon this category, questioning whether the relevant institutions and practices of the seventeenth century are similar enough to modern science to warrant the label 'scientific'. A central focus of their criticisms has been the identity of natural philosophy - the major discipline concerned with the study of nature in the early modern period - and its differences from modern science. This paper explores natural philosophy and its relation to philosophy more generally. It concludes that a significant philosophical revolution took place in the seventeenth century, and that this was important for the subsequent emergence of modern science.
\end{abstract}

In a series of lectures delivered in 1948 to the History of Science Committee at Cambridge, Herbert Butterfield introduced the idea of the Scientific Revolution. This event, he declared, 'outshines everything since the rise of Christianity and reduces the Renaissance and Reformation to the rank of mere episodes, mere internal displacements within the system of medieval Christendom'. According to Butterfield, in this episode lay 'the real origin of both the modern world and the modern mentality'. ${ }^{1}$ Hence, a proper understanding of the significance of the seventeenth-century rise of science necessitates an abandonment of the customary periodization of European history, and the elevation of the scientific revolution as the key event in the creation of the modern world. While Butterfield may be the best-known proponent of the idea of the Scientific Revolution, he was by no means alone in asserting that a monumental intellectual change had taken place in the seventeenth century. The Russian philosopher of science Alexander Koyré spoke of the seventeenth-century 'founders of modern science' and credited them with having destroyed the medieval world and replaced it with another. In his view, these figures developed a "new approach to being, a new concept of knowledge, a new concept of science'. ${ }^{2}$ Rupert Hall subsequently endorsed this 
judgement, suggesting that the early modern period witnessed the displacement of one world-view with another, resulting in a 'totality of intellectual change'. ${ }^{3}$ From the middle decades of the twentieth century, the Scientific Revolution quickly came to assume a prominent place in the West's understanding of its past, and stood alongside such events as the Renaissance, the Reformation, and the Enlightenment as a defining moment, if not the defining moment, in the birth of Western modernity. This idea also played an important role in galvanizing the fledgling discipline of the History of Science. 'Sci. Rev.' subjects, as they are known in the trade, became a mainstay of undergraduate history of science courses, and the Scientific Revolution became an important part of the public image of the history of science.

One of the features of historiographical discussions over the past decade, however, has been a growing disillusionment with standard periodization schemes. Once sacrosanct categories, such as the Reformation, the Renaissance, and the Enlightenment - movements which by successive stages were supposed to have given rise to the modern world - have found themselves subjected to increasing scrutiny. ${ }^{4}$ The idea of the Scientific Revolution has not been spared critical attention either, as a new generation of specialist historians of science, imbued with a horror of anachronistic 'Whig history' and possessed of a deep-seated aversion to grand narratives, have questioned whether we ought to speak of a scientific revolution at all. The now standard objection to the categorization amounts to the claim that there was not, in the seventeenth century, a unitary set of approaches to the natural world that were directly analogous to modern (i.e. twentieth- and twenty-first century) science. Neither, it is argued, did these various approaches to the study of nature undergo a sudden radical change. Rather, there were protracted changes that took place at different times within the various disciplines involved in the study of nature. ${ }^{5}$ Summarizing the current consensus amongst historians concerning the Scientific Revolution, Park and Daston observe that 'the cumulative force of scholarship since the 1980s has been to insert sceptical question marks after every word of this ringing three-word phrase, including the definite article' ${ }^{6}$

What then can be made of the idea of the Scientific Revolution? Is it possible to adopt the sensitivities of the current generation of historians of science and yet still maintain that there was a seismic shift in understandings of the natural world in the early modern period, and that this was a crucial transition in the formation of the modern West? I believe that it is, and in what follows I propose to focus on the two key criticisms of the concept: whether there was, in the seventeenth century, an intellectual 'revolution' and in what sense, if any, it might have been 'scientific'. 


\section{A revolution? Early modern perspectives}

One of the main trends in recent historiography of science has been an emphasis on the importance of 'actors' categories'. Historians who follow this agenda caution against foisting modern conceptions such as 'science' onto past figures, and argue that history should be concerned more with understanding how these individuals conceptualized their own activities. It is certainly true that when we attend to the ways in which figures such as Galileo, Boyle, and Newton refer to their own projects, we find them speaking about 'philosophy' or 'natural philosophy' and not much about 'science'. On the assumption that natural philosophy differs in important ways from modern science - and we shall explore this assumption in more detail - we may grant to critics of the Scientific Revolution that perhaps there was no 'science' in the seventeenth century to undergo a revolution. But was there a sense in which some early modern individuals imagined themselves to be participants in a momentous intellectual revolution of some kind, even if it were not, strictly speaking, a scientific revolution?

One of the key indicators of an incipient spirit of revolution among seventeenth-century thinkers was the constant invocation of 'the new' in discussions about knowledge - and this at a time when novelty in the realm of learning was not necessarily regarded as a virtue. A New Philosophy of the Universe (1591) was the bold title Francesco Patrizi chose for his attack on the prevailing Aristotelian natural philosophy. A few years later William Gilbert, in his pioneering De magnete (1600), claimed to be inaugurating 'a new style of philosophizing'. A number of his writings were posthumously published as $D e$ Mundo Nostro Sublunari Philosophia Nova (New Philosophy of our Sublunary World, 1651). Johannes Kepler's Astronomia nova (1609) proclaimed itself the herald of a new astronomy. Galileo spoke of two 'new sciences'. Francis Bacon's New Organon (1620) immodestly declared its author's ambition to usurp the old 'Organon' - the canon of Aristotle's logical works that occupied a central place in the university curriculum. René Descartes awoke from his 'night of dreams' with the conviction that he was destined to found a marvellous new science based on mathematical principles. Jean Baptiste van Helmont described 'a new rise and progress of philosophy and medicine. ${ }^{7}$

Such claims for novelty were not merely the immodest boasts of self-promoters although it must be conceded that some claims for originality were exaggerated. The impact of these new ideas was widely acknowledged and their significance hotly debated. The quarrel of the Ancients and Moderns, conducted in late seventeenth-century France and England, presupposed a sharp divide between ancient and modern learning, particularly for those who championed the superiority of the moderns. ${ }^{8}$ Significantly, perhaps, the ensuing compromise called for a distinction to be made between literary and scientific accomplishments, 
with the superiority of the moderns affirmed in the case of the latter, but not the former. The revolutionary and potentially destabilizing character of the new knowledge was well captured by John Dryden:

Is it not evident, in these last hundred years, when the Study of Philosophy has been the business of all the Virtuosi in Christendom, that almost a new nature has been revealed to us? That more errors of the School have been detected, more useful experiments in philosophy have been made, more noble secrets in opticks, medicine, anatomy, astronomy, discover'd, than in all those credulous and doting ages from Aristotle to us? - so true it is that nothing spreads more fast than science, when rightly and generally cultivated. ${ }^{9}$

Less celebratory, but more succinct, was the assessment of poet John Donne, who lamented that '[the] new Philosophy calls all in doubt.' 10

It is clear, then, that not only did many of those typically identified as leading figures in the Scientific Revolution consider themselves to be participating in a major new phase in the development of human learning, but that something of this spirit of novelty was also recognized by outsiders. Given this selfconsciousness about the new learning, it is not surprising that historical explanations were sought for it. Amongst the most common explanations offered were such factors as improvements in navigation and the voyages of discovery, or the invention of various devices and instruments, including the printing press. In the realm of natural history, explorers, colonizers and missionaries reported the discovery of 'many new things and secrets' of which the ancients had been completely ignorant. The Jesuit missionary Joseph de Acosta wrote that he found Aristotle's philosophy 'laughable' in the light of the newly discovered flora and fauna of the New World. Amerigo Vespucci pointed out that Pliny's natural history described fewer than one thousandth of the animal species of the Americas. Natural philosophers concurred with these assessments. Francis Bacon declared that 'by the distant voyages and travels which have become frequent in our times, many things have been laid open and discovered which may let in new light upon philosophy'. Later in the seventeenth century, Robert Boyle was to agree that the most lowly seaman to accompany Columbus on his voyages would have returned to Europe knowing 'an hundred things that could never be learned by Aristotle's philosophy.' ${ }^{11}$ The invention of the telescope and microscope also led to a remarkable expansion of the realm of nature by augmenting the limited human powers of vision. Descartes enthused that 'it is difficult to find any such inventions which do more to increase the power of sight than those wonderful telescopes which, though in use for only a short time, have already revealed a greater number of new stars and other new objects above the earth than we had seen there before'. The pioneer of microscopy, Robert Hooke, also spoke of 'a new visible world discovered to the understanding' through the use of telescopes and microscopes. 
The 'secret workings of Nature', hidden to ancients, were exposed to the moderns, who could now effect 'a reformation in Philosophy' 12

In addition to these more mundane and materially oriented explanations, the early moderns also sought to integrate their imagined revolution into the grand scale of human history. Not surprisingly, perhaps, the earliest reflections on the significance of the new advances in knowledge drew upon the prevailing periodizations of sacred history, looking back to the creation and forward to an imminent millennium. Thus, it was commonplace during the seventeenth century to make reference to the Genesis narratives of the Creation, and to the encyclopaedic knowledge once thought to have been possessed by Adam. Contemporary developments could be understood as attempts to restore a perfect Adamic knowledge that had been lost or compromised as a consequence of the Fall. Francis Bacon claimed that the goal of the new sciences was to restore the knowledge and dominion over nature that Adam had enjoyed in his prelapsarian state. ${ }^{13}$ Bacon also looked forward to impending eschaton, regarding the contemporary explosion of knowledge as part of a divine dispensation that would serve as a prelude to the end of the world:

Nor should the prophecy of Daniel be forgotten, touching the last ages of the world: - 'Many shall go to and fro, and knowledge shall be increased;' clearly intimating that the thorough passage of the world (which now by so many distant voyages seems to be accomplished, or in the course of accomplishment), and the advancement of the sciences, are destined by fate, that is, by Divine Providence, to meet in the same age. ${ }^{14}$

The great efflorescence of scientific and technological activity in England during the middle decades of the seventeenth century is clearly related to heightened millenarian expectations. ${ }^{15}$

It was also common, particularly amongst Protestant writers, to draw comparisons to the recent history of the Christian Church. The reformation of religion was thus understood as part of a more general reformation that was to affect all areas of human endeavour. Philosophical innovators were compared to such Protestant reformers as Luther and Calvin. ${ }^{16}$ Francis Bacon announced that the reformation of the Church was the catalyst for a more general reformation of learning. This was a common view that was later reprised by one of the early Royal Society's chief apologists, Bishop Thomas Sprat: 'This will be evident, when we behold the agreement that is between the present Design of the Royal Society, and that of our Church in its beginning. They both may lay equal claim to the word Reformation, the one having compass'd it in Religion, the other purposing it in Philosophy' ${ }^{17}$

In the eighteenth century, these religiously-inspired understandings of the significance of the new learning were to give way to the more secular notion of progress promoted by the advocates of the age of Enlightenment. According to 
the script of the philosophes, the scientific accomplishments of Bacon, Descartes, Newton and Locke were to be understood as having contributed to the liberation of the human spirit from the forces of superstition and religious dogmatism. Natural philosophers of the previous generation were thus retrospectively enlisted in the cause of Enlightenment, and the elevation of the significance of their accomplishments was accompanied by a corresponding diminution of the status of medieval achievements. In keeping with the anti-clericalism of the French Enlightenment, medieval Catholic Christianity was often identified as the institution responsible for stifling the spirit of scientific progress throughout the so-called Dark Ages - an assessment not inconsistent with the earlier judgements offered by Renaissance humanists and Protestant Reformers. The Marquis de Condorcet observed in this vein that 'the triumph of Christianity had been the signal for the complete decadence of philosophy and the sciences' ${ }^{18}$ Such a view was recapitulated in Burckhardt's influential divisions of history and was also rehearsed by some of the earliest historians of science, such as George Sarton, for whom the rise of science represented the victory of reason over religious superstition. ${ }^{19}$ Similar sentiments may be found in the works of Andrew Dickson White and John Draper to whom we are indebted for the erroneous yet surprisingly pervasive idea that science and religion have been in perennial conflict throughout Western history.

Returning to our main question: it may be allowed that no seventeenth-century figure used the term 'revolution' in relation to the contemporary advances in natural knowledge. But this is unremarkable, given that the more common meaning of 'revolution' in relation to temporal affairs was that of 'the recurrence of a previous age'. There were, however, numerous references to the 'revival', 'reformation', or 'instauration' of learning, or of 'new' philosophy or the philosophy of the 'moderns'. Moreover, such was the perceived significance of this event in the scale of human history that it was variously theorized as signalling the end of the world or, in more secular interpretations, as having inaugurated a new age of rational enlightenment. It can be concluded that while the terminology of 'revolution' may be the invention of twentieth-century historians, the underlying sentiment - that a monumental change in the realm of learning had taken place during the seventeenth century - was one with which many relevant historical actors themselves would have concurred. There remains, however, the further question: in what sense, if any, can this (admittedly protracted) revolution be regarded as a scientific one?

\section{Scientific or philosophical revolution?}

The most powerful argument of those sceptical about the scientific revolution concerns the identity of 'science' during the seventeenth century. In the sixteenth 
and seventeenth centuries the study of nature was carried out within a range of loosely related disciplines. Chief amongst them was natural philosophy, but also important were natural history, the 'mixed mathematical sciences' (such as astronomy and mechanics), anatomy, 'physic' (medicine), astrology, and alchemy. With the exception of alchemy and astrology, these fields bear some similarity to sub-disciplines of the modern sciences - natural philosophy might map onto physics and natural history onto biology, for example - however, in terms of their methods and mutual relations these earlier approaches to nature differ in significant ways from what we would call 'science'. Historians are generally agreed that 'natural philosophy', for example, is not a just a synonym for 'science', although making a positive case for exactly what natural philosophy might be has proven more elusive. ${ }^{20}$ That said, it is now widely accepted that natural philosophy had traditionally avoided mathematical treatment of its subject matter, and that one of the innovations of the early modern period was the novel introduction of mathematics into the sphere of natural philosophy. More controversially, it has been claimed that natural philosophy had a theological orientation and was essentially 'about God' ${ }^{21}$ If true, this would mark a clear difference between seventeenth-century natural philosophy and a modern science which almost invariably adopts the stance of methodological naturalism, thus placing theology beyond its scope. There is something to be said for each of these contentions, and they do point to important differences between natural philosophy and modern science. But the question of what was philosophical about natural philosophy has yet to be given a satisfactory answer. Further exploration of this question has the potential to shed light on both the question of the nature of natural philosophy and on how contemporaries viewed those dramatic changes in the realm of learning which, for the past 50 years, have been labelled the Scientific Revolution'.

A focus on philosophy may seem a strange way to approach the question of changes in what we would now regard as the natural sciences. However, if we allow the seventeenth-century witnesses to speak for themselves it is clear that when they speak of revolutionary change - consider the statements of Patrizi, Gilbert, Bacon, van Helmont, Hooke, Dryden and Donne cited above - they speak of the coming into being of a new philosophy, or a new way of philosophizing. To be sure, in certain cases this may be shorthand for natural philosophy, but even so, it is worth asking the question of the relationship between philosophy and the study of nature. Unfortunately, the history of philosophy, as traditionally understood, offers little assistance to those seeking to understand this early modern notion of a new mode of philosophizing. From the time of Kant, historians of philosophy have tended to assume that philosophy is a perennial discipline and that since the Pre-Socratics, philosophers have been concerned with more or less the same kinds of theoretical questions. Accordingly, the discussion with past 
philosophers has typically focused on their arguments and their doctrines. Some, however, have begun to express major reservations about this approach, and in a move similar to that which has taken place in the history of science, have asked how past philosophers themselves characterized their activities. Pierre Hadot, for example, has recently made convincing arguments to the effect that we need to re-imagine ancient philosophy as 'a way of life' rather than a body of philosophical doctrines. The goal of philosophy, he writes, was 'to provide a means for achieving happiness in this life, by transforming the individual's mode of perceiving and being in the world ${ }^{22}$ On this view, philosophical discourse, which now provides the principal subject matter of the history of philosophy, was for ancient philosophers secondary to the goal of moral or spiritual transformation.

If we adopt Hadot's intriguing suggestion, then we can begin to think about how the ends of natural philosophy might have been accommodated to this conception of philosophy and, in particular, how the contemplation of nature may also have had as its aim the attainment of wisdom. While it is not possible to make a strong case here for the contention that natural philosophy, prior to the modern period, was essentially oriented towards moral formation, a few instances may suffice to demonstrate the plausibility of this claim. Plato, for example, claimed that the lover of wisdom who becomes familiar with the divine order in the cosmos 'will himself become orderly and divine'.${ }^{23}$ In a sense, then, the ultimate purpose of studying the motions of the heavenly bodies was to regulate the interior motions of the soul. This conception of the goals of the study of nature is also found in the Almagest - one of the most important 'scientific' works of the Middle Ages. Here we find Claudius Ptolemy contending that study of the mathematical regularities of the heavens "makes its followers lovers of this divine beauty, accustoming them and reforming their natures, as it were to a spiritual state'. ${ }^{24}$ Medieval Christian thinkers, not surprisingly, found these ideas congenial, and incorporated them into Christianized natural philosophy. Thomas Aquinas wrote of the speculative sciences (theology, mathematics, natural philosophy), that their pursuit, ultimately, was directed towards perfecting the contemplative part of the soul. ${ }^{25}$ The English philosopher Roger Bacon, often identified as an important precursor to modern 'science', also contended that natural philosophy had a moral orientation: 'all speculative philosophy has moral philosophy for its end and aim'. ${ }^{26}$

In light of this, when we encounter early modern discourse about 'a new philosophy' or, more tellingly, about 'a new way of philosophizing', we might now think of it as referring not only to the new doctrines about the natural world that were emerging at different times and across a range of different disciplines, but also to a major reorientation of the goals of philosophy, a reorientation that will eventually produce not only something more akin to modern science, but also 
something more like modern philosophy, now distinct from both the study of nature and the business of moral formation, and with a focus on doctrines and arguments. A blueprint for such a reorientation was explicitly set out by Francis Bacon. Bacon's new vision of knowledge and its applications called for a shift away from the idea of philosophy as a solitary, contemplative practice, concerned primarily with the moral formation and happiness of the individual philosopher, to a communal activity, aimed at the mastery and manipulation of nature, for the benefit of the public. $^{27}$

Specifically, Bacon took issue with the idea that the study of nature is primarily a passive contemplative activity, to do with self-improvement and 'the quiet of resolution'. Rather, he insisted, natural philosophy should provide 'a rich store house, for the glory of God and the relief of man's estate'. The improvement of man's mind, the traditional goal of philosophy was not to be sundered from the improvement of the welfare of others. The potential of philosophy to improve human welfare also required that it become a communal activity, and one to which large numbers of individuals could contribute over time. A key to the success of such an endeavour was the adoption of a set of established procedures that were available to all. The success of the sciences, Bacon insisted, must depend not on the ability of a single inquirer, but on a succession of enquirers, bent to the same task and following an agreed method. ${ }^{28}$ In short, for Bacon, natural philosophy is not a private quest for enlightenment, but a collective and cumulative endeavour, generating a body of knowledge that is built up over time. Philosophy is less a contemplative practice than an active engagement with nature; it is characterized by known methods that in principle can be followed by individuals who differ in their natural capacities and abilities.

Although Bacon is generally regarded as having made no substantive contribution to science, his ideas about its goals and methods were influential and served as the inspiration for scientific societies both in England and Continental Europe. Certainly it should not be thought that Bacon was single-handedly responsible for the emergence of science in the modern West. Yet a consideration of his ideas points to a fruitful way of understanding what was revolutionary in the new approaches to knowledge characteristic of the seventeenth century. The new Baconian model of natural philosophy signals the beginning of a new attitude to learning - one that placed a value on public knowledge, on the accumulation of facts, and on practical outcomes related to human welfare. This underlying attitude was one that had a bearing on a range of quite disparate disciplines. This was indeed a revolution, and one in which it is possible to see the beginning of the two distinct paths of what we retrospectively call 'science' and 'philosophy'. 


\section{Conclusion}

There is no doubt that those sceptical of the idea of the scientific revolution are correct to point out that changes in the realm of learning during the seventeenth century were protracted and by no means universal. They are also right to insist that we should not speak of a 'scientific' revolution, as if there were some perennial activity 'science' of which modern science is simply the most advanced form. Despite this, it is clear that many individuals during the period in question believed themselves to be either participants in, or witnesses to, a special moment in history. My suggestion is that they were essentially correct in their assessment. If we can no longer characterize this moment as the Scientific Revolution, we can nonetheless search for the appearance of new attitudes and values that will promote what Stephen Gaukroger has recently called 'the emergence of a scientific culture'. ${ }^{29}$ Such changes, of the kind that we see exemplified in the writings of Francis Bacon, are as important as the discoveries and theoretical advances made by individual figures, and the social and material factors that made these possible. In sum, one of the distinctive features of the modern West, in addition to its vast store of scientific knowledge and its technological sophistication, is a set of values that views these developments positively. For the emergence of such values we can look to the seventeenth century.

\section{References and Notes}

1. H. Butterfield (1950) The Origins of Modern Science 1300-1800 (London: Bell), p. vii.

2. A. Koyré (1968) Galileo and Plato [1943] in Metaphysics and Measurement. Essays in the Scientific Revolution (London: Chapman and Hall), p. $20 \mathrm{f}$.

3. A. R. Hall (1983) The Revolution in Science 1500-1750 (London: Longmans), p. 3.

4. See, for example, on the Renaissance: T. K. Rabb (2007) Narrative, periodization, and the study of history, Historically Speaking 8, 2-4. On the Reformation: D. MacCulloch, M. Laven and E. Duffy (2006) Recent trends in the study of Christianity in sixteenth-century Europe, Renaissance Quarterly 59, 697-731; J. O'Malley (2000) Trent and All That: Renaming Catholicism in the Early Modern Era (Cambridge, MA, Harvard University Press). On the Enlightenment: J. Schmidt (2003) Inventing the enlightenment. Anti-Jacobins, British Hegelians, and The Oxford England Dictionary, Journal of the History of Ideas 64, 421-445; K. Baker and P. Reill (Eds) (2001) What's Left of Enlightenment? A Postmodern Question (Stanford: Stanford University Press); I. Hunter (2001) Rival Enlightenments (Cambridge: Cambridge University Press); J. Robertson (2005) The Case for the Enlightenment. Scotland and Naples 1680-1760 (Cambridge: Cambridge University Press). 
5. For a good summary of these points see M. J. Osler (2000) The canonical imperative: rethinking the scientific revolution, in M. J. Osler (Ed) Rethinking the Scientific Revolution (Cambridge: Cambridge University Press), pp. 3-22.

6. K. Park and L. Daston (Eds) (2006) The Cambridge History of Science. Volume 3, Early Modern Science (Cambridge: Cambridge University Press), pp. 12-13. See also S. Shapin (1994) The Scientific Revolution (Chicago: University of Chicago Press); H.F. Cohen (1994) The Scientific Revolution. A Historiographical Enquiry (Chicago: University of Chicago Press); D. Lindberg and R. Westman (Eds) (2003) Reappraisals of the Scientific Revolution (Cambridge: Cambridge University Press).

7. Galileo Galilei (1638) Dialogues Concerning Two New Sciences; William Gilbert (1600) De magnete, tr. P. F. Mottelay (New York: 1958), Author's preface, p. xlix; René Descartes Oeuvres de Descartes, 13 vols. Charles Adam and Paul Tannery (Eds) (Paris, 1897-1913), vol. 10, 156-57, 179; Jean Baptiste van Helmont, Oriatrike, or, Physick refined ... being a new rise and progress of phylosophy and medicine (London, 1662).

8. C. Perrault Parallèle des anciens et des modernes, 4 vols. (Paris, 1688-96); Bernard le Bovier de Fontenelle Digression sur les anciens et les modernes (1688) appended to Poésies pastorales (Paris, 1708); W. Temple An Essay upon the Ancient and Modern Learning (London, 1690). See also R. F. Jones (1936) The Battle of the Books (St Louis: University of Washington Press).

9. John Dryden An Essay of Dramatick Poesie (London, 1688), in Dryden's Essays (London: Dent, 1954), $10 \mathrm{f}$.

10. John Donne An Anatomy of the World, The First Anniversary.

11. Joseph De Acosta The Naturall and Morall Historie of the East and West Indies (London, 1604), 101. Francis Bacon, Novum Organum I, $\S 84$, in The Works of Francis Bacon, J. Spedding, R. Ellis and D. Heath (Eds), 14 vols (London, 1857-74), vol. 4, 82. Robert Boyle The Christian Virtuoso, in The Works of the Honourable Robert Boyle, 6 vols, T. Birch (Eds) (Hildesheim, 1966), vol. 5, 520.

12. René Descartes Optics, in The Philosophical Writings of Descartes, tr. J. Cottingham, R. Stoothoff, D. Murdoch, and A. Kenny (3 vols., Cambridge, 1984-91), vol. 1, 152. Robert Hooke Micrographia (London, 1667), Preface.

13. Francis Bacon Novum Organum, Bk. 2 \$2, in Works, vol. 4, 247. For the centrality of this theme in the seventeenth century see P. Harrison (2007) The Fall of Man and the Foundations of Science (Cambridge: Cambridge University Press).

14. Francis Bacon Novum Organum Bk 1, §93, Works, vol. 4, 92.

15. C. Webster (1975) The Great Instauration. Science, Medicine, and Reform, 1626-1660 (London: Duckworth).

16. See, for example, R.B. The Difference between the auncient Phisicke ... and the Latter Phisicke (London, 1585) Sigs. Cviii.v., Hvii.v. 
C. Webster (1982) From Paracelsus to Newton (Cambridge: Cambridge University Press), p. 4.

17. F. Bacon (1974) The Advancement of Learning, A. Johnston (Ed.) (Clarendon Press), p. 42; Thomas Sprat History of the Royal Society (London, 1666), 371. See also Thomas Culpeper Morall Discourses and Essayes (London, 1655), p. 63; Samuel Hartlib Sheffield University Library, Hartlib Papers XLVIII 17, reproduced in Webster The Great Instauration, Appendix 1, 524-28; Noah Biggs Mataetechnia Medicinae Praxeos. The Vanity of the Craft of Physick (London, 1651), To the Parliament.

18. Marquis de Condorcet Progress of the Human Mind, quoted in D. Lindberg (1992) The Beginnings of Western Science (Chicago: University of Chicago Press), p. 356.

19. George Sarton (1955) Introductory essay, in Science, Religion and Reality, Joseph Needham (Ed) (New York: George Braziller), p. 14.

20. See, for example, A. Cunningham (1991) How the Principia got its name: or, taking natural philosophy seriously. History of Science $\mathbf{2 8}$, 377-392; P. Dear (1998) The mathematical principles of natural philosophy. Toward a heuristic narrative for the Scientific Revolution. Configurations 6, 173-193; M. Osler (1997) Mixing metaphors. Science and religion or natural philosophy and theology in early modern Europe. History of Science 35, 91-113; C. Luthy (2000) What to do with seventeenth-century natural philosophy? A taxonomic problem. Perspectives on Science 8, 164-195.

21. A. Cunningham (1988) Getting the game right: some plain words on the identity and invention of science. Studies in History and Philosophy of Science 19, 365-389; (2001) Religion, science, and natural philosophy. thoughts on Cunningham's thesis. Studies in History and Philosophy of Science 32A, 377-386; E. Grant (2000) God and natural philosophy. the late middle ages and Sir Isaac Newton. Early Science and Medicine 6, 279-298; P. Harrison (2005) Physico-theology and the mixed sciences. The role of theology in early modern natural philosophy, in P. Anstey and J. Schuster (Eds) The Science of Nature in the Seventeenth Century (Dordrecht: Springer), pp. 165-183.

22. P. Hadot (2004) What is Ancient Philosophy? (Cambridge, MA: Harvard University Press); (1995) Philosophy as a Way of Life: Spiritual Exercises from Socrates to Foucault (Oxford: Blackwell). For similar perspectives see M.C. Nussbaum (1984) The Therapy of Desire (Princeton: Princeton University Press); B. Thomassen (1985) Metaphysik als Lebensform: Untersuchungen zur Grundlegung der Metaphysik im Metaphysikkommentar Alberts des Grossen (Munster: Aschendorff); M. Foucault (1988) The History of Sexuality, III: The Care of the Self (New York: Vintage); A. Nehamas (1998) The Art of Living. Socratic Reflections from Plato to Foucault (Berkley: University of California Press); J. Sellars (2003) The Art of Living. The Stoics on the Nature and Function of Philosophy (Aldershot: Ashgate); R. Sorabji (2003) Emotion and Peace of Mind. From Stoic Agitation to Christian Temptation, (Oxford: Oxford University Press); C. Condren, I. Hunter, 
and S. Gaukroger (Eds) (2006) The Philosopher in Early Modern Europe. The Nature of a Contested Identity (Cambridge: Cambridge University Press).

23. Plato Republic VI, 500d, Collected Dialogues, 736.

24. Ptolemy's Almagest, tr. G. J. Toomer (Princeton: Princeton University Press, 1998), p. 37.

25. Thomas Aquinas The Division and Method of the Sciences, tr. Armand Maurer (Toronto: Pontifical Institute, 1986), Q. 5 A. 1 Obj. 1.

26. Roger Bacon Opus Majus of Roger Bacon, tr. Robert Burke, (2 vols., Philadelphia: University of Pennsylvania Press, 1928), vol. 1, p. 72.

27. S. Gaukroger (2001) Francis Bacon and the Transformation of Early Modern Natural Philosophy (Cambridge: Cambridge University Press), p. 5 and passim; A. Pérez-Ramos (1996) Bacon's legacy, The Cambridge Companion to Bacon (Cambridge: Cambridge University Press), pp. 311-334.

28. Francis Bacon Novum organum I, §61, Works, vol. 4, 62; Bacon Novum organum, Preface, Works, vol. 4, 40; Bacon De sapientia veterum, Works, vol. 4, 753. Cf. Parasceve, Works, vol. 4, 252; Bacon, Great Instauration, Works, vol. 4, 18. See also Pérez-Ramos, Bacon's Legacy, Cambridge Companion to Bacon, 311-34 (315); P. Rossi (1968) Francis Bacon. From Magic to Science (Chicago: University of Chicago Press), p. 27.

29. S. Gaukroger (2006) The Emergence of a Scientific Culture. Science and the Shaping of Modernity, 1210-1685 (Oxford: Oxford University Press). A similar quest motivated Robert Merton's classic, and frequently misunderstood study, Science, Technology and Society in Seventeenth-Century England (1938).

\section{About the Author}

Peter Harrison is Andreas Idreos Professor of Science and Religion and Fellow of Harris Manchester College, University of Oxford. He is author of The Bible, Protestantism, and the Rise of Natural Science (1998) and The Fall of Man and the Foundations of Science (2007). 
